УДК 616.89-008.442.6

doi: $10.15330 /$ ps.10.1.80-88

\author{
Марія Клименко
}

Львівський національний університет імені Івана Франка

maria.klymenko@outlook.com

\title{
ФУНКЦІЇ НАРЦИСИЧНОЇ САМОРЕГУЛЯЦІЇ У КОНТЕКСТІ ОСОБИСТІСНОГО САМОЗДІЙСНЕННЯ
}

\begin{abstract}
У статті теоретично обтрунтовано та емпірично встановлено зв'язок нарцисичної саморегуляціі та особистісного самоздійснення. Нариисична саморегуляція - ие механізм саморегуляиії психодинамічного типу, щуо дбає про стабільність та иілісність Self-системи, позитивне сприймання себе, здорову самоиінність та самоповагу. Конкретизовано, щзо особистісна самоиінність - це умова відкритості до екзистениійних цінностей, які пропонує життя; змога обрати та наважитися реалізовувати власний життєвий вибір; готовність дбати про особистий сенс існування. Нариисична саморегуляція скерована на забезпечення потреб безпеки та повноцінного функціонування у соціальному середовищі; пошук та підтримання ціннісних орієнтирів, увінчуючи все потребами вести більш наповнене, осмислене життя, яке не фіксується лиш на самоствердженні, а розкриватиме себе у сповненості.

Зафіксовано, що загальний показник самоздійснення (сповненості) перебуває у зв'язку майже з усіма показниками функціонування нариисичної саморегуляції, зокрема рівнем нарцисизму та індексом функціонування системи Self. Виявлено, щзо особи з вищими показниками сповненості характеризуються більш наближеними значеннями індексу функиіонування загальної системи Self до значень ідеально сильного Self при зростанні рівня нариисизму. Натомість підвищений рівень нариисизму не виключає того, щчо саморегуляція виконує свою функиію навіть краще, ніж при рівні нижчому. Тож емпірично підтверджено, щзо відчуття власної цінності може бути однією з важливих умов формування екзистениійної відкритості до світу.
\end{abstract}

Статистично проаналізовано чинники сповненості, щуо лежать в основі функціонування нарцисичної саморегулящії, та виявлено, щуо ними є: сила Self, значущість Self, наявність особистісного ідеалу самодостатності, низька схильність до знецінювання інших людей, мени актуальне прагнення похвали та отримання нариисичної вигоди від захворювання, потреба в ідеальному Self-об 'єкті, помірно виражена потреба в іпохондричному захисті від тривоги. Отже, підтверджено, щзо нарцисична саморегуляція причетна до задоволення потреби у сенсі життя, оцінки життєвого досвіду як більш наповненого змістом.

Ключові слова: нариисизм, нариисична саморегуляція, Self-система, самоздійснення, екзистенційне самоздійснення, самоцінність, задоволеність життям.

Постановка проблеми та ії значення. Цінності та потреби сучасного суспільства передбачають зростання орієнтованості на власну індивідуальність. Розуміння своїх інтересів, особиста компетентність, досягнення, конкурентоздатність, суб'єктивне благополуччя та переживання щастя, самореалізація та самоздійснення стали суспільно схвалюваними якостями та цілями людини XXI століття. Як індивідуальний, так і груповий нарцисизм зростають та знаходять різноманітні способи вияву, будучи толерованими умовами теперішньої культури. Дуже часто, зокрема в актуальному українському суспільстві, побутує радше негативна конотація нарцисизму як певного світосприйняття, центрованого лише на власній персоні, випускаючи з поля зору, що самоцінність особистості, а власне ії брак, є підгрунтям для розвитку його патологічних форм. Особиста адекватно висока самоцінність $є$ необхідною умовою для налагодження більш функційних стосунків зі світом, а вміння бачити вартість у собі (запорука вміння помічати цю вартість і в навколишніх людях) і у житті, з усім його різноманіттям. Нарцисична саморегуляція - механізм формування адекватного уявлення про себе та більш позитивного самоставлення; кристалізація самоповаги, що має на те підстави; а переживання та підтримування власної самоцінності є джерелом саморозкриття та саморозвитку. Тому питання емпіричного вивчення зв'язку цього регулятивного механізму, що інтегрує Self із спроможністю переживати екзистенційне самоздійснення, як стан та процес, є достатньо актуальним. Важливо також спробувати конкретизувати, що з елементів нарцисичної саморегуляції є більш дотичним до переживання особистісної сповненості загалом. 
Аналіз останніх досліджень проблеми. Вивчення нарцисичної саморегуляції в континуумі перехідних форм (від патологічних до здорових станів) найбільш грунтовно здійснюється в рамках психодинамічної парадигми: від ортодоксального психоаналізу, а далі Еgo-психології, теорії об'єктних стосунків та екзистенційно-психоаналітичного підходу. Власне в рамках теорії об'єктних стосунків сформовано найглибшу теоретичну базу вивчення не лише дисфункційного нарцисизму, але й конкретизовано особливості його конструктивних форм, вивчається питання «нарцисичного дефіциту», що є умовою компенсації браку особистої цінності. Х.Кохут визначив нарцисичну саморегуляцію як механізм задоволення нормальних потреб Self, брак якого може породжувати проблеми 3 відчуттями, викликати дезінтеграцію Self, спричиняти нарцисичну фасадність; О. Кернберг звертає увагу на адекватний нарцисизм дорослого як спосіб підтримання відносно стабільного позитивного уявлення про себе, основу адекватної самооцінки і прояву амбіцій та ідеалів[1]. Проблема нарцисичної саморегуляції представлено також у більш сучасних працях Дж. Міллера, Дж. Прайса, К. Морф, Д. Фостера, К. Кембела, Р. Раскіна, Г. Террі, С. Робінс. Ф. Денеке визначає нарцисичну саморегуляцію як механізм підтримання позитивного уявлення особистості про себе (самоцінність) [6]. К. Морф та Ф. Родвальд розуміють нарцисичну саморегуляцію як систему персональних стратегій зв'язку особистості з ситуацією, що стимулюється потребою в досягненні [1]. Н. Шварц-Салант вказує, що нарцисична структура притаманна всім людям у нормі, а нарцисичні риси в різних формах вияву можуть маніфестуватися задовго до фіксації патологічних станів; це аспекти певних психологічних патернів, що завжди входять у психологічну структуру творчої особистості на шляху їі самоздійснення [4].

Предметом цього дослідження є «здорові» форми нарцисизму, що перебуває в межах діагностичних компетенцій емпіричного дослідження.

Особистісне самоздійснення найбільш грунтовно вивчається у рамках екзистенційної психології, що представлена В. Франклом, Р. Меєм, А. Ленгле, О. Орглером, І. Яломом, Д. Леонтьєвим, і стосується знаходження сенсу життя, відкритості екзистенційним смислам, виборам та екзистенційній відповідальності, формуванню особистісних сенсожиттєвих орієнтацій $[8,9]$, віднайдення гармонії в екзистенційній конфронтації з такими вимірами існування, як ізоляція, буття у суспільстві, особистісна свобода, неминучість смерті [5]. А. Гевірт визначає самоздійснення як спосіб втілення персональних цінностей в індивідуальному та соціальному вимірах [7]. Часто, зокрема у працях А. Ленгле, використовується синонімічне поняття «екзистенційне самоздійснення», або «сповненість» що аналогічно визначаються як рух глибоко в середину власної особистості, розкриття персонального у власному бутті, а через переживання особистісної цінності - здатність бути відкритим щодо екзистенційних вартостей життя. Буття у світі, наповненому смислами; самоздійснення у процесі самовираження та просоціальних орієнтацій життєдіяльності; самоздійснення як форма суб'єктності особистості крізь призму самодетермінації також аналізується у працяхтаких українських дослідників, як Т. Титаренко, Б. Братусь, I. Гуляс, І. Болотнікова.

Мета статті полягає в емпіричному вивченні нарцисичної саморегуляції як чинника особистісного самоздійснення.

Методи та методики. Методологічним підгрунтям емпіричного дослідження нарцисичної саморегуляції як чинника особистісного самоздійснення слугувала теза: інтегрованість Self та ефективно функціонуюча нарцисична саморегуляція пов'язані з осмисленим та автентичним існуванням людини. Досліджено 360 осіб віком від 17 до 25 років, які є студентами вищих навчальних закладів м. Львова. Методики дослідження: Тест оцінки нарцисизму «Self» (Ф. Денека та Б. Хільгеншток), «Шкала екзистенції» (А. Ленгле), опитувальник «Задоволеність життям» (Е.Дінер). Отримані дані опрацьовано за допомогою методів багатовимірної статистики (Statistica 8.0 та Exel): кореляційного та регресійного аналізів. 
Виклад основного матеріалу дослідження. Нарцисична саморегуляція - це механізм підтримання афективної рівноваги всередині цілісної Self-структури, що дбає про іiї стабільність, цінність та позитивне ставлення до власної особистості. Це самостійний та важливий для психічного здоров'я феномен, що підтримує та організовує Self в автентичній мозаїці його сприймань та когніцій, інтелекту та переживань, пам'яті та фантазій, сукупності всього життєвого досвіду, інтер- та інтрапсихічної активності [6]. Нормальний нарцисизм є адаптивним способом регуляції самооцінки, самоставлення, формування та підтримання адекватного уявлення про себе, а центральним елементом та показником ефективності саморегуляції $є$ відчуття особистої цінності. Втрата відчуття власної цінності, самоповаги або ж навпаки їі екстремально високе відхилення від реальності інформують про дестабілізаційні зміни у Self-структурі та дисфункційність перебігу саморегуляції. За своєю природою нарцисична саморегуляція $\epsilon$ динамічним явищем, що врівноважує такі принципи та потреби, як віднайдення спокою та рівноваги, пошук сенсорно-афективних стимуляцій. Тож одним з ії центральних завдань $\epsilon$ підтримання орієнтації особистості на новий досвід, освоєння нових можливостей та нових форм самовираження як прояву неповторної індивідуальності [6].

Самоздійснення - це одночасно процес, стан та результат: процес віднайдення особистої ідентичності та сенсу життя, результат відкритого до екзистенційних цінностей буття особи, стан автентичного та наповненого сенсом існування. Екзистенційне самоздійснення - реалізація власної духовної компоненти, що у термінах екзистенційно-психоаналітичної психології має назву Person (це персональне як унікальне та вільне в людині) $[2,7]$. Така реалізація персонального в людині здійснюється засобами самотрансценденції, здатності до самодистанціювання, усвідомлення власної свободи та відповідальності [8]. Умовами наповненого сенсом екзистенційного існування є: змога «бути»; відчуття того, що життя - це добре; можливість та право бути власне собою [3]. Усі зазначені вимоги торкаються проблеми особистої цінності, яка, на думку А. Ленгле, є детермінантою та опорою здатності відчувати цінності життя;змоги відкрити власну Person крізь слід, який цінності залишають у інтер- та інтраперсональному досвіді людини.

Самоцінність $є$ тим феноменом, що постає між самоздійсненням та нарцисичною саморегуляцію, поєднуючи їх між собою. Тож можна припускати, що у разі ефективнішого функціонування нарцисичної саморегуляції стає можливою й більш зріла екзистенційна позиція суб'єкта, який крізь призму довіри до себе та власних оцінок стає резистентнішим щодо дестабілізаційних впливів зовнішнього середовища. Саме такого роду довіра $\epsilon$ умовою готовності до екзистенційного «Діалогу» зі світом, змоги пізнати Person та piшучості втілити персональний задум у реальність, що і виражає екзистенційну сповненість суб'єкта, його самоздійснення.

\section{Результати емпіричного дослідження}

Для вивчення загальних зв'язків нарцисичної саморегуляції та самоздійснення використано кореляційний аналіз даних усі єї досліджуваної вибірки.

3'ясовано, що сповненість як загальний показник осмисленості життя перебуває у прямому кореляційному зв'язку 3 інтегративним показником нарцисизму $(\mathrm{r}=0,43)$ та індексом функціонування системи Self $(\mathrm{r}=-0,49)$, що зі зростанням показників сповненості наближається до показника профілю ідеально сильної особистості та свідчить про конструктивний вплив нарцисичної саморегуляції на підтримання цілісності та стабільності Self, позитивне ставлення до себе. Зафіксовано зв'язок зростання показникасповненостіз такими параметрами нарцисичної саморегуляції, як: безсиллям Self $(\mathrm{r}=-0,64)$; схильністю до втрати контролю над емоціями та прагненнями $(\mathrm{r}=-0,38)$; потребою у використанні психологічних захистів типу деперсоналізації чи дереалізації для протистояння дестабілізаційним впливам середовища $(\mathrm{r}=-0,45)$; незначущістю Self $(\mathrm{r}=-0,58)$; негативним образом власного тіла $(\mathrm{r}=-0,46)$; соціальною ізоляцією $(\mathrm{r}=-0,41)$; потребою в архаїчному догляді як регресивній спробі уникання реальності $(\mathrm{r}=-0,40)$; прагненням похвали $(\mathrm{r}=-0,16)$; переживанням нарцисичного гніву $(\mathrm{r}=-0,34)$; знецінюванням об'єктів $(\mathrm{r}=-0,42)$; іпохонд- 
ричним захистом від тривоги $(\mathrm{r}=-0,19)$ та отриманням нарцисичної користі від захворювання як більш зрозумілого способу пояснення життєвих невдач $(\mathrm{r}=-0,30)$. Водночас виявлено прямий кореляційний зв'язок сповненості із наявністю базового потенціалу надії $(\mathrm{r}=0,30)$ та внутрішнього ідеалу самодостатності $(\mathrm{r}=0,28)$, а також із задоволеністю життям $(\mathrm{r}=0,41)$, що не менш важливо.

В свою чергу окремі показники сповненості сформували таку кореляційну структуру з наричисизмом (таблиця 1):

Табличя 1

Зв'язок нарцисизму з показниками екзистенційного самоздійснення

\begin{tabular}{|l|l|}
\hline $\begin{array}{l}\text { Показники екзистенційного } \\
\text { самоздійснення }\end{array}$ & $\begin{array}{l}\text { Нарцисизм } \\
r=\ldots \text { при } p<0,01\end{array}$ \\
\hline Екзистенційність & 0,39 \\
\hline Самотрансценденція & 0,40 \\
\hline Свобода & 0,40 \\
\hline Відповідальність & 0,32 \\
\hline Самодистанціювання & 0,21 \\
\hline Персональність (Person) & 0,39 \\
\hline
\end{tabular}

Отже, динамічна система Self та особливості їі функціонування перебувають у тісному зв'язку з переживаннями особистісного самоздійснення. Особи з вищими показниками сповненості характеризуються вищими показниками нарцисизму, що, проте, перебувають у межах норми, оскільки показники індексу функціонування системи Self свідчать про його високу інтегрованість та функційність. Нарцисична саморегуляція підтверджує свою причетність до задоволення потреби у сенсі життя, схильності до більш осмисленого існування та оцінки власного досвіду як збагаченого внутрішнім персональним сенсом. Особи, у яких загальний рівень осмисленості життя є вищим, ніж в інших, характеризуються більш адекватним типом регуляції з боку Self загалом та нарцисичної саморегуляції зокрема. Це свідчить про гнучкість, стресостійкість, позитивне ставлення до себе, що є джерелом відчуття власної цінності й умовою здатності бачити цінності в світі, наповненому сенсами. Це розгортає для людини нові можливості, нові переживання, збагачує способи та форми самовираження.

Досліджувані, у яких вища сповненість поєднується зі зростанням нарцисизму, характеризуються:

- більшою силою Self (екзистенційна тривога, страх самотності, соціальних обмежень їм менш властиві);

- адекватним самоконтролем емоцій та спонукань (різноскеровані емоції й прагнення перебувають у більш ефективному балансі);

- рідшим використанням дереалізації /деперсоналізації (найчастіше в умовах екстремальних, коли дисоціативне розщеплення захищає від непомірної сили розбалансовуючих впливів) та архаїчно-регресивних тенденцій «втечі» від реальності, що свідчить про більшу включеність у реалізацію своїх планів зміни персональної дійсності;

- вищим базовим потенціалом надії як джерела установки на реалізацію особистісних ресурсів всупереч можливим труднощам;

- відчуттям власної значущості;

- більшим прийняттям своєї зовнішності та можливих дефектів (навіть якщо фізичні дефекти існують, вони не сприймаються надміру загострено, а інтегруються у цілісну Self-структуру);

- слабшою соціальною ізоляцією (впевненість у собі та ефективна саморегуляція дозволяють краще розкривати свої думки і почуття навколишнім, співпрацювати 3 ними, не вдаючись до маніпуляцій, а шляхом довірливого взаємного обміну);

- більш контрольованими реакціями нарцисичного гніву (у випадках загрози самоцінності), що мало шкодять стабільності Self;

- меншою залежністю від уваги навколишніх (що, в свою чергу,не вказує на повну байдужість до похвали чи на заперечення стимулювального впливу позитивної суспільної 
думки на почуття впевненості, підвищення продуктивності. Адже думка навколишніх основа адекватної самооцінки);

- меншою схильністю до знецінювання, заздрості та песимізму (загалом стратегія знецінення $\epsilon$ формою подолання нарцисичних фрустрацій раннього дитинства та $\epsilon$ властивою особам із дисфункційним типом нарцисичної саморегуляції);

- зростанням показників ідеалу самодостатності як відповідальності перед собою й орієнтації насамперед на власні зусилля у досягненні мети;

- визнанням можливості захворіти важко, проте це не провокує нестерпну тривогу при незначних ознаках фізичного нездужання та не стоїть на заваді самоздійсненню.

Встановлено, що особистісна сповненість перебуває у прямому кореляційному зв'язку із задоволеністю життям, а саме більш позитивною емоційною оцінкою різних його сторін. Нарцисична саморегуляція дбає про такий афективний баланс, при якому радше надається більша вага тому досвіду та інтрапсихічним явищам, що є більш позитивними [10].

Вивчаючи чинники особистісного самоздійснення, що належать до показників нарцисичної саморегуляції, здійснено загальний регресійний аналіз, результати якого представлені у таблиці 2, поданій нижче.

Таблиия 2

Показники коефіцієнта регресії чинників особистісного самоздійснення

\begin{tabular}{|l|l|}
\hline Чинники самоздійснення & Beta \\
\hline Безсилля Self & $-0,34$ \\
\hline Незначущість Self & $-0,24$ \\
\hline Ідеал самодостатності & 0,14 \\
\hline Знецінювання об'єктів & $-0,19$ \\
\hline Прагнення похвали & $-0,14$ \\
\hline Прагнення до ідеального Self-об'єкту & 0,11 \\
\hline Іпохондричний захист від тривоги & 0,09 \\
\hline Нарцисична вигода від захворювання & $-0,09$ \\
\hline
\end{tabular}

Переживання суб’єктивної впевненості, спроможності, відчуття психічної цілісності, наявність мети діяльності, позитивна самооцінка, відчуття внутрішнього наповнення, що говорять про силу Self, не тільки перегукуються зі змістом особистої сповненості, але і $є$ iї визначальними чинниками. За Ф.-В. Денеке: «реалістичне почуття власного безсилля для сильної особистості уявити можна, проте воно не повинно мати характер нестерпності» [5]. Тобто з наростанням особистого безсилля, яке суб' єктивно сприймається як втрата відчуття внутрішньої готовності взаємодіяти зі світом, змоги конструктивно протистояти проблемам, знімати токсичність розбалансовувальних впливів ззовні та зсередини - продукується схильність швидше до екзистенційних фрустрації та пустки при спробі осмислити суб'єктивне існування.

Функційний тип нарцисичної саморегуляції спрямований на підтримання уявлення особистості про себе як особи значущої (соціально успішної, ефективної). Емпірично виявлено, що особистісна значущість (ії суб'єктивна рефлексія) є другим чинником, що здійснює вплив на переживання себе особою, яка сповнюється. Зростання показників незначущості Self вказує радше на неадекватне відчуття невпевненості, низьку здатність до детоксикації почуття сорому при переживанні невдач, конфліктів, соціальної чи професійної некомпетентності тощо. Натомість базова впевненість у собі та високий рівень соціабельності $є$ необхідними умовами більш відкритого ставлення до світу. Сильна особистість також зазнає невдач та фрустрацій з можливими негативними наслідками, проте вона здатна зберігати внутрішнє переконання, що базова впевненість у собі та базова безпека цілковито ii не покинуть. Таким чином підтверджується теза А.Ленгле, що внутрішня сила особистості, здатність протистояти обтяжливим життєвим обставинам, розвиненість самоцінності, відкритість до себе та інших, усвідомлення власних потреб та 
обов'язків забезпечують функціонування такої особистісної структури, яка створює умови доступу до буття Person [2].

Ідеал самодостатності як одна із центральних характеристик сильної особистості також є необхідним чинником особистісного самоздійснення. Ідеал самодостатності - це впевненість у собі, відповідальність за прийняті рішення та персональна стійкість при їх реалізації. Засобами прийняття безумовної цінності власного Self кристалізується персональна готовність добре ставитися до себе. Особа, «виправдана у своїх власних очах» [8], готова більш адекватно сприймати оцінки навколишніх. Формується готовність перебувати зі світом у «Діалозі», що є умовою втілення особистого смислу в бутті.

Несхильність до знецінювального ставлення $є$ також чинником, що здійснює вплив на особистісне самоздійснення. Адже знецінення навколишніх - зворотна сторона переживання власної меншовартості. Натомість сильніша особистість менше потерпає від заздрощів та ій менш притаманний знецінювальний стиль міжособистісних взаємин. Схильність знецінювати може давати поштовх фрустрації цінності екзистенційної свободи та здатності відповідально взаємодіяти зі світом [2]. Крізь призму браку персональної самоцінності дуже складно побачити цінність того, що людину оточує; доступне смислове феноменологічне поле стає неймовірно обмеженим, а особа - скутою в своїх екзистенційних виборах. Захист від власного знецінення стає бар'єром для розвитку спроможності роздивитися цінності, що могли б зробити існування більш осмисленим.

Попередні висновки плавно переходять в осмислення четвертого чинника самоздійснення - потреби в похвалі та підтвердженні своєї вартості, що повинна бути нижчою у тому сенсі, що сильній особистості не притаманна залежність від думки оточення. Загалом, ми продовжуємо обгрунтовувати одну й ту ж тезу: нарцисичний дефіцит стимулює використання арсеналу захисних та компенсаторних механізмів, що певною мірою ослаблюють особистість, заважають їй відкритися екзистенційним можливостям, які пропонує Буття.

Ще одним чинником особистісного самоздійснення є прагнення до ідеального Selfоб'єкту. В силу певних обставин частина вибірки, що характеризується вищим рівнем сповненості, потребує черпати натхнення від певних ідеалізованих об'єктів. Припускаємо, що такий ідеалізований об'єкт існує не лише у вимірі зовнішньому[6], проте може бути й інтерналізованим у вигляді натхненного образу. Ідентифікація з ним стимулює особу, наче дозволяє черпати сили від ідеалізованого об'єкта. Прагнення до ідеального Self-об'єкту є свого роду толеруванням важливості соціальних контактів через надання значення авторитетам, захоплення їхньою харизмою. Цей параметр як чинник самоздійснення наштовхує на думку про важливість інтерналізованих та інтегрованих в особистісну структуру об'єктних стосунків, що є необхідним ресурсом та моделлю ставлення до власного Self.

Водночас можна здійснити припущення щодо вікової особливості досліджуваних (особи від 17 до 25 років): юнацький період та рання дорослість характеризуються потребою в пошуку ідеалів та «натхненників», життєві позиції яких стимулювали б до віднайдення власних життєвих цінностей крізь призму наявних, вже декларованих сенсів. Тут роль внутрішнього авторитету грає і достатньо розвинене Super-Ego як моральний імпратив особистого обов'язку та відповідальності. На думку А. Ленгле,екзистенційна відповідальність за власні рішення перед собою, світом та навколишніми людьми - необхідна умова розвитку самоцінності та іiі постійне підтвердження [8]. Також варто уточнити, що за умови конструктивної нарцисичної саморегуляції ми маємо справу не із жорстоким, звинувачувальним та засоромлювальним Супер-Его, але із досить зрілим. Тобто за умови функційної інтеграції Self, когнітивно-оцінкових функцій Супер-Его, консолідації, ревізії та здатності підтримувати індивідуальний та суспільно узгоджений моральний кодекс можна говорити про більш «здорову» самоповагу та самоцінність, здатність кристалізувати особистісні цінності та сенси. Ймовірно, за наявності такого внутрішнього образу ми спираємося на внутрішньоособистісний стержень, що мав би акумулювати особистісні ресурси задля подолання життєвих негараздів, бути ресурсною 
частиною власного ідеалу, віддзеркалюванням фантазії про ідеально сильне Self. Такі фантазії можуть стимулювати індивіда до розвитку та турботи про особистісні потреби, додавати відчуття впевненості у персональних рішеннях.

Іпохондричний захист від тривоги також є чинником особистісного самоздійснення. Варто зазначити, що майже повсюдно у вибірці найвищі зафіксовані показники лише незначно відхиляються від показників профілю ідеально сильної особистості. Це свідчить про те, що сильна особистість може припускати виникнення серйозного захворювання, але на сигнали нездужання відповідатиме адекватною тривогою. У такому разі зберігається внутрішня сила задля протистояння загрозам Self-фрагментації та деструкції його саморегулятивних функцій, адже людина векзистенційно-аналітичній теорії є системою трьох вимірів: тілесного, психічного та духовного. Тому розуміння власного тіла, що підпорядковується законам «хвороби та здоров'я» $є$ базою емоційно-оцінкового ставлення до власного Self. Приймати та «витримувати» себе, не відщеплюючи частини Self, які перебувають у конфлікті, є шляхом прийняття не лише власної особистості - наслідком внутрішніх зрушень буде вибудовування довіри до навколишніх людей та світу загалом.

I на завершення: нарцисична вигода від захворювання $є$ негативним чинником особистісного самоздійснення. слабкість Self проявляє себе крізь призму зниження схильності до ефективної компенсації можливих фізичних обмежень (вроджених або набутих, тимчасових чи тривалих захворювань). У випадку ефективного функціонування нарцисичної саморегуляції особа здатна краще помічати потенційні можливості реалізації життєвих планів [6]. Перешкодою для переживання особистісного самоздійснення може бути конфліктне уявлення про ідеальне Self та тілесні перешкоди, які використовуються для пояснення невдач та проблем. Несвідомо переживаючи страх та відчуваючи небезпеку у конфронтації з особистою неуспішністю, індивід ізолює тілесні проблеми 3 цілісного уявлення про Self, порушуючи необхідні засади особистісного самоздійснення: прийняття себе i, як наслідок, світу. Почуття довіри до світу також базується на здатності взаємодіяти 3 різними частинами власного Self, бачити цінність навіть у перешкодах, які є шанс долати або ж компенсувати. Страждання - це природна складова частина життя. Не лише радість його визначає [3].

Висновки. Теоретично проаналізовано зв'язок нарцисичної саморегуляції з переживанням особистісного самоздійснення. Виявлено, що самоцінність є явищем, що тісно пов'язує обидва феномени. Емпірично підтверджено: високий нарцисизм, поєднаний із більш ефективним функціонуванням Self-системи, крокує поруч зі зростанням показника самоздійснення. Тобто здорова самоцінність може бути умовою відкритості до екзистенційних змін суб'єкта, більш осмисленого його існування.

3'ясовано, що чинниками особистісного самоздійснення, що належать до структури нарцисичної саморегуляції, є: сила Self, переживання його значущості, ідеал самодостатності. Протилежними чинниками є: схильність ставитися до навколишніх знецінююче й потреба похвали. Базова впевненість у тому, що власна особа має цінність та володіє достатньою силою, аби дбати про себе, ухвалювати рішення, здійснювати їх відповідально дає змогу рішучіше йти назустріч екзистенційним сенсам, які пропонує життя. Це важлива умова здатності помічати, бачити і приймати цінності, здійснювати екзистенційну зміну всередині себе. За таких умов людина швидше стає відкритою до самоздійснення, дає змогу екзистенційним цінностям відгукнутися у глибинах персонального. Без відчуття самодостатності, довіри до себе та власних рішень, без самоповаги та прийняття усіх сторін Self Person не може проявитися, оскільки самоздійснення - це здатність «зустріти себе», відповідати за себе, ставитися до власного Self турботливо, бути вільним перед собою та самодостатнім у соціальній взаємодії.

Перспективою подальшихдослідження може бути вивчення динаміки психологічних змін у роботі з людьми, що потерпають від депривації екзистенційних сенсів персонального існування (у форматах психологічного консультування, психотерапії, орієнтованої на психологічну стабілізацію та вироблення рефлексивної культури, а саме 
турботи про власне Self). Не менш важливим є вивчення соціально-психологічних умов життя та особливостей їх сприймання особистістю залежно від типу функціонування нарцисичної саморегуляції.

1. Клименко, М. Р. (2018). Нарцисична саморегуляція особистісного самоздійснення. Психологія особистості, 1 (9), 44-50.

2. Лэнгле, А. (2002). Грандиозное одиночество. Нарциссизм как атропологически экзистенциальный феномен. Московский психотерапевтический журнал, 2, 34-58.

3. Лэнгле, А. (2016). Жизнь наполненная смыслом. Логотерапия как средство оказания помощи 8 жизни. М.: Генезис.

4. Шварц-Салант, Н. (2007). Нарииссизм и трансформация личности. М.: «Класс».

5. Ялом, И. (1999). Экзистенцииальная психотерапия. М.: «Класс».

6. Deneke, F.-W. (1994). Die Regulation des Selbsterlebens bei Gesunden, psychosomatischen, psychoneurotischen und alkoholkranken Patientenein taxonomischer Forschungsansatz. Psychotherapie, Psychosomatik und medizinische Psychologie, 44, 260-280.

7. Gewirth, A. (1998). Self-Fulfillment. Princeton University Press.

8. Längle, A. (2014). From Viktor Frankl's Logotherapy to Existential Analytic psychotherapy. European Psychotherapy, 12, 67-837.

9. Loonstra, B., Brouwers, A., Tomic, W. (2007). Conceptualization, construction and validation of the Existential Fulfillment Scale. European Psychotherapy, 7, 5-17.

10. Pavot, W., \& Diener, E. (1993). Review of the Satisfaction with Life Scale. Psychological Assessment, 5 (2), 164-172.

\section{REFERENCES}

1. Klymenko, M. (2018). Nartsysychna samorehuliatsiia osobystitsnoho samozdiisnennia [Narcissistic Selfregulation of personal fulfillment]. Psykholohiia osobystosti, 1 (9), 44-50. (ukr.).

2. Lengle, A. (2002). Grandioznoe odinochestvo. Nartsissizm kak antropologicheski ekzistentsialnyiy fenomen [Grandiosity of loneliness. Narcissism as an anthropologically existential phenomenon]. Moskovskiy psihoterapevticheskiy zhurnal, 2, 34-58. (rus.).

3. Lengle, A. (2016). Zhizn napolnennaya smyislom. Logoterapiya kak sredstvo okazaniya pomoschi $v$ zhizni [Life filled with meaning. Logotherapy as a way of life assessment]. M.: Genezis. (rus.).

4. Shvarts-Salant, N. (2007). Nartsissizm i transformatsiya lichnosti [Narcissism and personality transformation]. M.: «Klass». (rus.).

5. Yalom, I. (1999). Ekzistentsialnaya psihoterapiya [Existential psychotherapy]. M.: «Klass». (rus.).

6. Deneke, F.-W. (1994). Die Regulation des Selbsterlebens bei Gesunden, psychosomatischen, psychoneurotischen und alkoholkranken Patientenein taxonomischer Forschungsansatz. Psychotherapie, Psychosomatik und medizinische Psychologie, 44, 260-280.

7. Gewirth, A. (1998). Self-Fulfillment. Princeton University Press, 6-12.

8. Längle, A. (2014) From Viktor Frankl's Logotherapy to Existential Analytic psychotherapy. European Psychotherapy, 12, 67-837.

9. Loonstra, B., Brouwers, A. Tomic, W. (2007). Conceptualization, construction and validation of the Existential Fulfillment Scale. European Psychotherapy, 7, 5-17.

10. Pavot, W., \& Diener, E. (1993). Review of the Satisfaction with Life Scale. Psychological Assessment, $5(2), 164-172$.

\section{Maria Klymenko \\ FUNCTIONS OF NARCISTIC SELF-REGULATION IN THE CONTEXT OF PERSONAL SELF-FULFILLMENT}

The connection between narcissistic self-regulation and personal self-fulfillment is theoretically investigated and empirically analyzed in the article.Narcissistic self-regulation is a psychodynamic mechanism, which cares about the stability and integrity of the self-system, positive perception of oneself, healthy self-esteem and self-value. It was specified that personal self-value is a condition of openness to existential values. It gives the ability to choose and take a venture to implement personal own life choice, to take care of the personal meaning of existence.Narcissistic self-regulation is aimed at finding and maintaining value orientations, living a meaningful life, which is not fixed only on self-affirmation, but is revealing itself in the existential fullness.

It was investigated that the overall indicator of self-fulfillment stays in connection with almost all indicators of narcissistic self-regulation: the level of narcissism and the index of the self- function in particular.Individuals with higher level of self-fulfillment are characterized by more «healthy» self-regulation as well. And the level of narcissism also increases. A slightly higher level of narcissism does not exclude that selfregulation performs its important functions, but performs even better than at a lower level.So it was empirically confirmed that the feeling of own value can be one of the most significant conditions for the formation of existential openness to the world and personal fulfillment.. 
The factors of self-fulfillment underlying the functioning of narcissistic self-regulation were statistically studied. Such factors are: self-power, self-importance, the presence of a personal self-sufficiency ideal, low propensity to devaluation of other people, less actual desire for praise and receipt of narcissistic benefits from the disease, the need to have an ideal Self-object, the need to act hypochondriacally in order to protect oneself from anxiety.

Therefore, it has been confirmed that narcissistic self-regulation has an involvement in satisfying the needs in the sense of life, assessment the life experience as more existentially content.

Keywords: narcissism, narcissistic self-regulation, self-system, self-fulfillment, existential self-fulfillment, self-value, satisfaction with life. 